\section{Thrice-Weekly Supplementation Adequate for Cows on Pine-Bluestem Range ${ }^{1}$}

\author{
H. A. PEARSON AND L. B. WHITAKER
}

Principal Range Scientist and Range Technician, Southern Forest Experiment Station, Forest Service, U.S. Department of Agriculture, Pineville, Louisiana.

\section{Highlight}

Cows and calves on pine-bluestem range in Louisiana did as well when fed a winter supplement on Monday, Wednesday, and Friday as when they received feed daily.

Cow herds grazing southern forest ranges require supplemental feed during winter, since the forage then is seriously deficient in protein and other nutrients. General practice is to distribute the feed daily, but in a Louisiana study during 1964 to 1967 herds fed every second day did as well as a herd fed daily. ${ }^{2}$ Because lengthening the distribution interval reduces labor costs, it was decided to observe results from feeding three times a week.

The herd that had been fed daily was still intact. It was therefore placed on a Monday-WednesdayFriday schedule from 1968 through 1970, and its performance compared with its earlier record.

\section{Range and Herd Management}

The cattle ran yearlong on the Palustris Experimental Forest in central Louisiana. Three range units totaling about 1,600 acres were stocked for light, moderate, and heavy grazing. Stocking rates were 26, 20, and 13 acres per animal unit. Annual herbage production averaged about 2,000 pounds per acre. Slender bluestem (Andropogon tener) and pinehill bluestem (A. divergens) were the main grasses. Range units were burncd in rotation on a 4-year cycle.

Cows were typical native stock of mixed breeding. They were mated for winter calving; calves were weaned and marketed in mid-August when about 7 months old.

Between November 1 and May 31 cows received approximately 400 pounds per head of cottonseed cake, fed in open troughs. Amounts fed per cowday are indicated in Table 1.

From mid-January until late March grass hay

\footnotetext{
${ }^{1}$ Received November 20, 1971.

${ }^{2}$ Duvall, V. L. 1969. Comparison of supplementation methods for cow herds grazing pine-bluestem range. J. Range Manage. 22:182-187.
}

Table 1. Amounts (pounds) fed per cow-day.

\begin{tabular}{lccc}
\hline & & \multicolumn{2}{c}{ Thrice-weekly schedule } \\
\cline { 3 - 4 } Period & $\begin{array}{c}\text { Maily } \\
\text { schedule }\end{array}$ & $\begin{array}{c}\text { Monday } \\
\text { and Friday }\end{array}$ & Wednesday \\
\hline November 1-30 & 1 & $2 \frac{1}{2}$ & 2 \\
December 1-31 & $21 / 2$ & $6 \frac{1}{4}$ & 5 \\
January 1-March 10 & 3 & $7 \frac{1}{2}$ & 6 \\
March 11-31 & 2 & 5 & 4 \\
April 1-May 31 & 1 & $2 \frac{1}{2}$ & 2 \\
\hline
\end{tabular}

was furnished at a rate of 3 or 4 pounds per cow-day on the same schedule as cake; the total was about 250 pounds per cow. Steamed bonemeal and loose salt were supplied free-choice, and intakes averaged 15 and 21 pounds per cow-year, respectively.

\section{Cattle Performance}

Calf crops averaged somewhat higher when the herd was fed three times weekly than when it had been fed daily (Table 2). Calf weaning weights were about equal for both schedules. Daily calf gains from spring weighing to weaning were also about the same; the advantage, if any, was with the thrice-weekly schedule. On both schedules, calf crops were better on the lightly grazed range unit than on those grazed moderately or heavily.

The cows averaged between 775 and 845 pounds and were in similar condition before and after both feeding trials. Apparently, therefore, thrice-weekly supplemcntation was not detrimental to the breeding herd.

Transportation and labor per distribution in-

Table 2. Three year averages of calf crops and weights from cows fed daily and thrice weekly.

\begin{tabular}{lccc}
\hline \hline $\begin{array}{c}\text { Grazing intensity } \\
\text { and feeding } \\
\text { method }\end{array}$ & $\begin{array}{c}\text { Calf crop } \\
\text { weaned (\%) }\end{array}$ & $\begin{array}{c}\text { Adjusted } \\
\text { weaning } \\
\text { weight (lbs.) }\end{array}$ & $\begin{array}{c}\text { Daily gain } \\
\text { spring to } \\
\text { weaning (lbs.) }\end{array}$ \\
\hline $\begin{array}{l}\text { Light } \\
\text { Daily }\end{array}$ & 78 & 403 & 1.7 \\
$\quad$ Thrice weekly & 84 & 419 & 1.8 \\
$\begin{array}{l}\text { Moderate } \\
\text { Daily }\end{array}$ & 70 & 387 & 1.6 \\
Thrice weekly & 72 & 387 & 1.7 \\
Heavy & & & \\
Daily & 65 & 399 & 1.6 \\
Thrice weekly & 71 & 397 & 1.7 \\
\hline 1 Adj. weaning wt. $=\left(\frac{\text { weaning wt. }-65}{\text { age }}\right) 205+65$ & \\
\end{tabular}


crease only slightly when feedings are spaced out. formance of the herd, indicate that the extended The longer schedule therefore saves about $43 \%$ of schedule may provide an economical and effective such costs. Further, it eliminates the need for week- means of augmenting nutritionally deficient range end labor. These advantages, plus the good per- diet during winter. 